https://doi.org/10.4316/CC.2020.02.007

\title{
INFO-ANALYTICAL SUPPORT FOR UKRAINIAN-POLISH CROSS-BORDER COOPERATION. THE EURO-REGIONS CASE STUDY
}

\author{
Antonina SHULIAK ID , Yevheniia VOZNIUK iD, \\ Iryna PATLASHYNSKA $\mathbb{D}$, Nazarii SHULIAK \\ Lesya Ukrainka Volyn National University (Ukraine) \\ E-mails: antonina.mytko@vnu.edu.ua; voznyuk.yevhenija@vnu.edu.ua; \\ iryna.patlashynsyka@vnu.edu.ua; nazarii.shuliak@vnu.edu.ua
}

\begin{abstract}
This article discusses the cross-border collaboration between the territorial communities and local authorities in Ukraine and Poland in terms of cooperation activities focused on the objectives of their economic, social, scientific, technical, environmental and cultural relations. The authors study the Euroregions as the primary form of cross-border cooperation $(C B C)$. The interpretation of the information support for $C B C$ has been determined in the context of its activities. Furthermore, it has been examined within the framework of the "Carpathian" and "Bug" Euro-regions through the following elements: the organisational and legal system (agreements, Programs, etc.); institutions that help collect, process and disseminate data on the CBC (websites, blogs, etc.); info-analytic products of the Euro-regions (articles, media reports, etc.). The authors highlight issues related to the information support for Ukrainian-Polish $C B C$ and formulate the recommendations on how to improve the informational component of Ukrainian-Polish CBC within the "Carpathian" and the "Bug" Euro-regions.
\end{abstract}

Keywords: information support, cross-border cooperation (CBC), projects, Ukraine, Poland.

Rezumat. Suport informațional-analitic pentru cooperarea transfrontalieră ucraineană-poloneză. Studiu de caz: Euroregiunile. Acest articol analizează colaborarea transfrontalieră între comunitățile teritoriale și autoritățile locale din Ucraina și Polonia din perspectiva activităților de cooperare axate pe obiectivele relațiilor lor economice, sociale, științifice, tehnice, de protecție a mediului și culturale. Autorii au cercetat euroregiunile ca forma principală a cooperării transfrontaliere

Copyright (C) 2020 “Codrul Cosminului”, XXVI, 2020, No. 2, p. 431-454. 
(CBC). Interpretarea suportului informaţional pentru CBC a fost realizată în contextul activităților desfășurate. Mai mult, în cadrul euro-regiunilor „Carpatică” și „Bug” au fost examinată următoarele elemente concrete: sistemul organizațional și juridic (acorduri, programe etc.); instituțiile care ajută la colectarea, prelucrarea și diseminarea datelor privind CBC (site-uri web, bloguri etc.); produsele informațional-analitice ale acestor euro-regiuni (articole, rapoarte media etc.). Autorii evidențiază problemele legate de sprijinul informațional pentru CBC ucraineano-polonă și formulează recomandări cu privire la modul de îmbunătățire a componentei informaționale a CBC ucraineanopolonă în cadrul euro-regiunilor „Carpatică” și „Bug”.

\section{INTRODUCTION}

Each country has its own unique and emblematic history. The peoples belonging to the modern states have lived on different parts of their borders for centuries. Still, the common elements of their languages and similar cultures, customs and traditions have been preserved. The past, present and future of each nation are intertwined as the neighbouring countries have uneven development in border regions. The European Community pays particular attention to the development of programs initiated by its border regions. At the same time, it supports interstate and external cooperation within the framework of partnership initiatives with its neighbours.

As part of the state policy, the current cross-border cooperation (CBC) occupies an important place in the system of priorities of socio-economic development or in the European integration processes of Ukraine. Ukraine has excellent growth potential due to its favourable geopolitical position. Its 19 out of 25 regions are border regions, and the external state border is the longest in Europe, including $1,390 \mathrm{~km}$ of borderland with EU member-states. The particular aspects of Ukrainian cross-border cooperation lie in the fact that they occur at the EU borders and borders with Russia, Belarus, and the Republic of Moldova. The main form of Ukrainian-Polish CBC includes the activities carried out by the "Carpathian" and "Bug" Euroregions.

In the first instance, the framework of categories and concepts that characterise the cross-border cooperation system must be defined. Thus, any inter-territorial cooperation is treated as a coordinated activity aimed at the relations initiated by two or more contracting parties' territorial communities and authorities. Exceptions are given by cross-border cooperation relations between neighbouring powers, including agreements between local and 
regional authorities and state authorities. ${ }^{1}$

The legal bases of inter-regional cooperation outline territories that rank second after the central ones (Ukrainian regions and the Autonomous Republic of Crimea, Kyiv and Sevastopol, and concerning Poland - its voivodeships, etc.).

Various relationships, such as trade, economic, cultural, scientific, tourism, are maintained and developed within the system of cross-border cooperation. Cross-border cooperation relations are the basis and an integral part, as a subsystem, of the structure of modern international relations. Simultaneously, cross-border collaboration is a specific area of international and interstate relations implemented and developed according to precise criteria and principles. ${ }^{2}$

\section{THE EUROREGION AS THE MAIN FORM OF CROSS-BORDER COOPERATION}

As defined by national law, any cross-border cooperation is carried out under the territorial communities or authorities' jurisdiction. It has been found that the term is used in the scientific literature to cover territories of intensive cross-border cooperation in all spheres of life. These are the aggregate border territories of two or more neighbouring states that have cross-border cooperation, with a high or potential level of access. ${ }^{3}$

The Euroregion can simply be defined as a territorial unit formed by two adjacent sub-national units belonging to two separate states. ${ }^{4}$ This does not necessarily imply any compromise for cooperation and can even be considered as a simple geographical definition. However, as the same authors have pointed out, this concept is primarily used in the context of the CBC activities. It implies a certain degree of institutionalisation, as demonstrated by agents' interaction

${ }^{1}$ Protocol No. 2 to the European Framework Convention on Cross-border Co-operation between Territorial Communities or Authorities, Concerning Inter-territorial Cooperation (1998, 5.05), Strasbourg.

${ }^{2}$ Євген Кіш, Проблеми транскордонного співробітництва України і Євросоюзу [Problems of the Cross-border Cooperation between Ukraine and the European Union], in http://www.politik.org.ua/vid/magcontent.php3?m=1\&n=63\&c=1412 (Accessed on 12.02.2020).

3 Дмитро Стеченко, Розміщення продуктивних сил і регіоналістика [Productive Forces Deployment and Regionalism], Київ, Вікар, 2006, 396 с.

${ }^{4}$ Markus Perkmann, Cross-Border Regions in Europe: Significance and Drivers of Regional Cross-Border Co-operation, in "European Urban and Regional Studies", 2003, 10(2), p.153-171. 
on both sides of the border. Similar definitions proposed by other authors focus on the idea that can be seen in Eduardo Medeiros's work. ${ }^{5}$ This can undoubtedly be one common feature of each Euroregion, even though some entities labelled as Euro-regions may have more work to do in the field of European interregional cooperation.

When considering the main reasons behind CBC initiatives, Kramsch \& Hooper ${ }^{6}$ have presented additional arguments in favour of the above explanation, revealing the real purpose of the Euro-regional structures. However, according to them, the attempt to rewrite border areas once considered marginal and peripheral to nation-states' territorial projects concerning those at the very heart of Europe. It differed from them by some centrality dynamism is common among Euroregional initiatives. Therefore, it is no coincidence that the Commission itself refers to its cross-border regions as "laboratories for European integration." 7 In addition to the common purpose, the institutionalisation shapes, territorial dimensions, geographical profiles, and the pursued objectives can considerably vary across different structures.

A cross-border cooperation agreement may stipulate a cross-border cooperation body ${ }^{8}$ (e.g. Euroregion, as a structural subdivision of public authorities, etc.). Additionally, an important aspect of the regional development is interregional and cross-border cooperation, born among border regions and territories, and resulted in the creation of the Euroregions in their progressive form, involving collaboration among administrative and territorial units carried out under bilateral or multilateral CBC agreements.

Currently, the Euroregions have a cross-border space management system covering all border regions along the state border perimeter. It must assume absolute coordination of the cross-border areas that are developing within the regional governance system and ensure their competitiveness internally and globally, outside it. The Law of Ukraine "On Cross-Border Cooperation" gives the following definition of the term: "The Euroregion is an

5 Eduardo Medeiros, (Re)defining the Euroregion Concept, in "European Planning Studies", 2011, 19(1), p. 141-158; Eduardo Medeiros, Euro-Meso-Macro: The New Regions in Iberian and European Space, in“Regional Studies", 2013, 47(8), p. 1249-1266.

${ }^{6}$ Barbara Hooper, Olivier Kramsch (eds.), Cross-border governance in the European Union, Taylor \& Francis, 2004.

${ }^{7}$ Antoni Durà Guimerà, Francesco Camonita, Matteo Berzi, Andrea Noferini, Euroregions, Excellence and Innovation across EU borders, in "A Catalogue of Good Practices", Barcelona, Department of Geography, UAB, 2018, 254 p.

${ }^{8}$ Additional Protocol to the European Framework Convention on Cross-border Cooperation between Territorial Communities and Authorities, November 9, 1995. 
organisational form of cooperation, carried out by administrative and territorial units of European states under bilateral or multilateral agreements on cross-border cooperation."9

Experts from the "East-West Institute" Centre have extended this interpretation. According to them, the Euroregion is a form of cross-border cooperation between territorial communities or local authorities of border regions of two or more states, having a common border. Such partnership aims to coordinate mutual efforts and their implementation, agreed in various spheres of life according to national and international laws, either to solve common problems or for the benefit of the people inhabiting its territory on both sides of the border. ${ }^{10}$

Today, there are between 120 and 183 Euroregions in Europe, but some of them have just declared their creation. Moreover, there are more than 100 Euroregions in Western and Central Europe. Most Euroregions are located at the borders with Germany (31), France (15), Sweden (16), Finland (10), as well as Poland (18), Czech Republic (13), Bulgaria (14), Hungary (15) and Romania (13).11

The Ukrainian and Polish sides actively support the creation of such forms of cross-border cooperation. Since the early 1990s, two Euroregions have been established at the borders of Ukraine and Poland, the "Carpathian" Euroregion involving Poland, Ukraine, Slovakia, Hungary and Romania (1993) and the "Bug" Euroregion consisting of the Polish, Ukrainian and Belarusian regions (1995).

A special institutional level of CBC between Ukraine and Poland was developed in the first half of the 1990s during the emergence of the "Carpathian" and "Bug" regions as important centres of Ukrainian-Polish intensification and development of interregional and cross-border cooperation. The "Carpathian" Euroregion, involving participants from the Ukrainian side (Lviv, IvanoFrankivsk, Transcarpathia, and Chernivtsi regions) and the Polish side (the Subcarpathian Voivodship), ${ }^{12}$ was created on February 14, 1993, and signed in Debrecen (Hungary) by the Ministers of Foreign Affairs of Ukraine, Poland and

\footnotetext{
9 Закон України "Про транскордонне співробітнищтво" [Law of Ukraine "On CrossBorder Cooperation"], in http://zakon3.rada.gov.ua/laws/show/1861-15 (Accessed on 12.02.2020).

${ }^{10}$ На шляху до Європи. Український досвід євро-регіонів [On the way to Europe. Ukrainian experience of Euro-regions], К.: Логос, 2000, с.94-95.

${ }^{11} A E B R$, in aebr.eu (Accessed on 28.07.2020).

12 Euroregion "Karpaty", in http://euroregionkarpaty.com.ua (Accessed on 12.05.2020).
} 
Hungary. It was founded on the Declaration for the Cooperation of Communities Residing in the Carpathian Region and the Statute Instrument of the Interregional Association - "Carpathian" Euroregion.

The Agreement on the Creation of a Cross-Border Association "Bug" Euro-region ${ }^{13}$ was signed on September 29, 1995, in Lutsk, between Volyn region and the former Chełm, Lublin, Tarnobrzeg and Zamość Voivodeships of the Republic of Poland (now, the Ukrainian side is represented by the Volyn region, Zhovkiv and Sokal districts of Lviv region, and the Polish side - by the Lublin Voivodship). ${ }^{14}$

\section{INTERPRETATION OF INFORMATION SUPPORT IN THE CONTEXT OF EUROREGION ACTIVITIES}

An important and integral part of cross-border cooperation is its informational support. All CBC solutions in European countries with a long history of cross-border processes and developed legislation receive appropriate information support. They have information support corresponding to their needs. Without such support, any CBC can be risky and lead to unexpected and negative results. According to the authors of the study, Ukraine lacks such experience in providing information. Therefore, research on the development of general principles and generalisation of experience in implementing various aspects of the information support for CBC becomes relevant.

A clear and unambiguous understanding of the information support content has not yet been achieved. Noting the "information support" in the title of research materials, their authors replace it with such concepts as "information", "information processing methods", "mass media", "press", etc. As a rule, the information support is considered a set of organisational and technical measures or actions. Its aims at generating certain information, sufficient or necessary for taking managerial decisions, narrowing it down to only one aspect organisational, which is precisely the biggest problem of any information support.

As P. Bielienkyi, N. Mikula and Ye. Matvieiev points out that the importance of information support for cross-border cooperation is to "stimulate the information infrastructure development, especially in border and cross-

${ }^{13}$ Euroregion "Bug", in http://euroregionbug.maps.arcgis.com (Accessed on 12.05.2020).

${ }^{14}$ Інформаційне забезпечення транскордонного співробітництва України: методичні аспекти [The Information Support for Cross-Border Cooperation of Ukraine: methodological aspects], Луцьк, Вежа-Друк, 2015, 252 c. 
border areas. It covers the arrangement of legal, economic, technical conditions for the practical information exchanges between the subjects and participants in cross-border cooperation and informs the business community and the public on cross-border cooperation issues and provides the feedback in return."15

One can only agree with the position proposed by Serhii and Anna Tovkanets ${ }^{16}$ that an influential factor improving the market organisation is the introduction of information systems opened for participants involved in crossborder cooperation. These systems will contribute to the formation of virtual organisational structures, characterised by the advantages of external (market) and internal (within the firm) interactions and will save time and money on finding partners and concluding deals. "The present open systems include communication tools (official sites of the 'Carpathian' and 'Bug' Euroregions), regional promotional sites, microsites, information and analytical products (articles, messages, videos, audio stories in the media, etc.)."

Therefore, it is advisable to consider the information support content in a broader context - primarily in socio-political, as well as in economic, technical, etc. plans. Thus, the cross-border cooperation information support is considered a targeted activity of stakeholders associated with the gathering, recording, processing, collecting, protecting and use of messages and any other data necessary for the full and effective operation of these entities, to implement cross-border cooperation functions. These include organisational and legal systems (agreements, programs, etc.), institutions collecting, processing and disseminating the information concerning the CBC (websites, blogs, etc.), information and analytical products of the activities of the Euroregions (articles, messages, video, audio in the media, etc.). In general, there are two subsystems in the information support system: information communication (information exchanges through communication channels and tools), and info-analytic subsystems (whose role is to develop fundamentally new data for the decision-making process, and statistics).

15 Петро Бєлєнький, Надія Мікула, Євгеній Матвєєв, Конкурентність на транскордонних ринках [Competitiveness in cross-border markets], Львів, 2005, с. 33.

16 Сергій Товканець, Ганна Товканець, Інформаційне забезпечення міжнародного бізнесу в рамках транскордонного співробітнищтва [Information support of international business in the framework of cross-border cooperation] іп Актуальні проблеми економіки [Current problems of the economy], 2010, 10 (112), с. 282. 


\section{STRATEGIC INSTRUMENTS AND PROGRAMS AS THE BASIC INFORMATION SUPPLY FOR CBC ORGANIZATIONAL AND LEGAL SYSTEMS}

The evaluation of the strategic documents relative to Ukrainian and Polish interstate policies and the institutions responsible for their implementation has shown that only a few of them are actually functioning and having some influence on the CBC policy despite their considerable number, in general. Currently, the Ukrainian-Polish contractual framework includes about 200 agreements, treaties, and other bilateral international instruments. The agreement on local border traffic, the Polish Card law, and many others are among them. ${ }^{17}$

The Ukrainian-Polish inter-regional cooperation's main legal instrument is the Intergovernmental Agreement "On the Interregional Cooperation", concluded between Ukraine and the Republic of Poland, which is in force, but what it needs is vision. Separate CBC strategies in Lviv, Transcarpathia, Ivano-Frankivsk, and Volyn regions as well as in Poland (Subcarpathian Voivodship) are absent therein. Instead, there is a "Cross-Border Cooperation Strategy for the Lublin Voivodship, Lviv, Volyn and Brest Regions for 2014-2020", which is mostly formal.

The ENI Poland-Belarus-Ukraine Cross-Border Cooperation Program (2014-2020) ${ }^{18}$ is the document that defines the most important issues of the Program implementation, its content, objectives, and operability. This document outlines the interest areas of joint Projects, which will be implemented through four thematic objectives and the respective priorities. The achievements of the Program are evaluated through objectively verified indicators. Some of the product indicators are based on "Common Product Indicators" of the CBC European Neighbourhood Instrument (ENI), developed by the European External Action Service (EEAS) with the help of the Interactive Instrument - the European Neighbourhood and Partnership Instrument (ENPI), to facilitate the verification and disclosure at instrument level.

${ }^{17 Z ̇ a n n a ~ O s i k o w i c z, ~ W s p o ́ ł p r a c a ~ t r a n s g r a n i c z n a ~ U k r a i n y ~ i ~ P o l s k i ~ w ~ s t r u k t u r z e ~ s t o s u n k o ́ w ~}$ międzynarodowych na przykładzie wybranych euroregionów (zarys i problematyka) [Cross-border cooperation of Ukraine and Poland in the structure of international relations on the example of selected euroregions (outline and issues)], in"Zarządza niew Kulturze" [Management in Culture], 2017, 18, z. 2, s. 237-249.

${ }^{18}$ ENI Poland-Belarus-Ukraine Cross-Border Cooperation Program 2014-2020, in https://www.pbu2020.eu/en/pages/251 (Accessed on 12.05.2020). 
ENI supports sustainable development at the EU external borders, helps to equalise its residents' living standards and solve common problems across borders. In terms of budget, the Poland-Belarus-Ukraine Program is the most extensive ENI CBC Program at the EU borders: $€ 165$ million allocated to projects aimed at protecting and promoting the cultural and natural heritage of border areas, the transport infrastructure of regions, the improvement of border checkpoints, in particular their infrastructure, and the development of health and public safety services.

The present Program Strategy has been adopted at the request of the Managing Authority, according to the realised socio-economic analysis. The analysis has identified common national and regional priorities of the member countries and their relevant regions. It has also been based on the previous programming experience. Moreover, the Program Strategy has considered the different views of parties on the common needs and problems of the Program area. Besides, it reflects decisions on thematic areas, where member-countries can solve their problems and control common assets.

Both the creation and the implementation of common strategies relative to regional development are essential factors for the activation of such crossborder regions. The practice of an identical approach used for regional strategic governance, regardless of location at national borders, is quite common. The priorities of their development are unilaterally formulated, taking into consideration the states' interests and goals, developing a strategy, without coordinating with the priorities of the cross-border partners. Therefore, it is necessary to create designs, sharing common goals, priorities, guidelines, and specific actions, using the cross-border potential to enhance the competitiveness of neighbouring border regions. The Polish state strategies, given below, are an example of such instruments. ${ }^{19}$

Concerning the Polish Strategies (Krajowa Strategia Rozwoju Regionalnego 2010-202020, and Strategia Rozwoju Województwa Lubelskiego ${ }^{21}$ ),

${ }^{19}$ Bohdana Korop, Andrzej Miszczuk, Czynniki peryferyzacji i aktywizacji regionów transgranicznych z udziałem Ukrainy - próbaujęcia typologicznego [Peripheral factors and activation of cross-border regions with the participation of Ukraine anattempt at a typological approach], in "Wiadomości Statystyczne" [Statistical News], 10 (689), 2018, p. 5-20.

${ }^{20}$ Krajowa Strategia Rozwoju Regionalnego 2010-2020 [National Strategy for Regional Development 2010-2020], in http://www.mrr.-gov.pl/rozwoj_regionalny/polityka _regionalna/ksrr_2010_2020/Strony/Krajowa_Strategia_Rozwoju_Regionalnego_ 2010_2020.aspx (Accessed on 12.02.2020).

${ }^{21}$ Strategia Rozwoju Województwa Lubelskiego [Development Strategy of the Lubelskie 
their focus is mainly on their regional balance with other regions, on the building of their territorial unity, and the marginalisation processes, combating the problem areas. The Polish region competitiveness is achieved via the strengthening of large cities' role and the development of human resources, intellectual and social capitals. Moreover, the Poles need to find support for the localisation of external investments, expand possibilities to absorb innovations by enterprises and regional institutions, develop the business environment, guarantee the energy efficiency, react to climate changes and cultural heritage usage, and provide help for Polish regions to stay competitive.

The development strategy for the Subcarpathian Voivodship for 20072020 highlights that the proximity to Ukraine of the present Voivodship allows intensifying cooperation with Ukrainian regions. Institutional frameworks have been created there for collaboration through several economic missions and business meetings. As a result, closer cooperation has been established with the signing of cooperation agreements with Lviv, Volyn, Ivano-Frankivsk and Odesa regions. ${ }^{22}$

Additionally, Poland has a Strategy for Socio-Economic Development of Eastern Poland until 2020.23 Since 2004, the EU's border has passed along the eastern frontier of Poland; thus relations with its eastern neighbours, including Ukraine, have impacted Poland's international image in the European Union and mainly in Europe. Furthermore, the Strategy states that if Ukraine becomes a candidate country for the EU membership in the nearest future, the number of funds, allocated by the European Union to develop cooperation with its neighbours, will increase and facilitate the evolution of further relations between Ukraine and Poland. Therefore, Poland will stimulate the processes of mutual approach between the European Union and Ukraine. The regional development supported along the border with Ukraine is one of such a strategy's key priorities.

Therefore, it should be pointed out that the cross-border cooperation information support involves international agreements with the Central Bank of

Voivodship], in http://www.-rpo.lubelskie.pl/front/page/get/281/.94 (Accessed on 12.02.2020).

${ }^{22}$ Strategia Rozwoju Województwa Podkarpackiego [Development Strategy of the Podkarpackie Voivodeship], in www.podkarpackie.pl/strategia/strat_woj.pdf (Accessed on 12.02.2020).

${ }^{23}$ Strategia rozwoju społeczno-gospodarczego z Polska do 2020 roku [Strategy for socioeconomic development from Poland to 2020], in http://www.polskawschodnia.gov.pl/Dokumenty/Lists/Dokumenty\%20program owe/Attachments/93/Strategia_PW_po_RM.pdf (Accessed on 12.02.2020). 
the Russian Federation (CBR), agreements on the creation of Euroregions and agreements among regional bodies of administrative and territorial units of neighbouring states. They all have a systemic nature and set the main goals, objectives and principles of inter-regional and cross-border cooperation between the state-partners. They have become the normative and legal basis for developing multi- and bilateral relations among Ukraine, Poland and the EU countries.

\section{UKRAINIAN-POLISH CBC COMMUNICATION TOOLS AND INFORMATION PRODUCTS: INFO-ANALYTIC SUPPORT}

Information support requires the coordination of the conditions to exchange targeted information and build and disseminate data. Four functions are performed by the information support for CBC between Poland and Ukraine: informational, ensuring the setup of an "information base" that reflects the image of the $\mathrm{CBC}$ event; normative, responsible for the socialisation process associated with $\mathrm{CBC}$; an organisational group set to manage a set of material relations to ensure the reliability of data functions; and an intermediary (medial), establishing ties among society structures.

All information support for cross-border cooperation is provided by cooperating with the subjects and objects of the CBC informational support system with various specialists, the public, and the media. Several specialised institutions, developed in multiple organisational forms, play an active and creative part in this process.

Therefore, such structures include the "Infostat" cluster. The partnership agreement on the creation of the scientific information and statistical cross-border "Infostat" cluster, with the participation of the Ukrainian and Polish parties, signed on March 20, 2013, has become a typical example of cooperation within the Euroregions in the area directly related to information support of cross-border cooperation between Ukraine and Poland. It has been concluded by the Institute for Regional Studies of NASU, the Main Department of Statistics in Lviv region, Ivan Franko Lviv National University, Lviv Regional Union of Economists of Ukraine on the Ukrainian side, and by the Statistical Office of the Subcarpathian Voivodship (Rzeszow), Rzeszow University, the Centre for Statistical Research and Education of the GUS of Poland, on the Polish side. ${ }^{24}$ The purpose of the cluster is to facilitate cooperation in the field of scientific, information and

${ }^{24}$ Статистичний кластер [Statistical Cluster], in http://www.lv.ukrstat.gov.ua/ CBC/ua/project/project_all.php?u=4\&l1=1 (Accessed on 12.02.2020). 
statistical support for the development of the Ukrainian-Polish cross-border regions, to create a system of regional statistics to monitor the socio-economic phenomena, to conduct scientific and statistical surveys in border areas, as well as to develop the Ukrainian-Polish cross-border region web portal.

The CBC public administration information mechanism, involving Ukraine and the EU countries, allows the development of cross-border statistics, information dissemination through official sites, communication events, and social networks. However, the conducted analysis proves that the present system of collecting and monitoring statistical data in CBC in Ukraine has not been sufficiently developed. Collection, processing, and analysis of statistical information in Poland are performed by a special department of the Central Statistical Office of the Centre for Research of Cross-Border Regions and Euroregional statistics ${ }^{25}$, which constantly monitors such cross-border processes. Executive and local self-government bodies often use roundtable discussions, workshops, conferences with a small number of participants, to disseminate information. Less than $50 \%$ of regional authorities use social networks to communicate any cross-border information. Therefore, the inefficient $\mathrm{CBC}$ information support at the state level causes the weak activity of the CBC bodies and does not allow a qualitative assessment of the situation on the cross-border markets and take effective decisions.

To improving the information support, it is required to ensure openness and easy access to any information on existing cross-border projects and financial resources, allocated for their implementation. Public awareness of government initiatives on both sides of the border is aimed at solving crossborder problems, as well as at the governmental organisational tools that will be used for this purpose (e.g., diplomatic institutions and their activities, visits to regions of foreign countries and international delegations, etc.). The availability of the information portals, where interested professionals and civic activists will be able to receive information on current educational programs, future conferences, and seminars that will take place in the field of crossborder cooperation both in Ukraine and abroad, as well as the information on exhibitions and fairs, are considered as significant elements, too. ${ }^{26}$

25 Ośrodek Badań Obszarów Transgranicznych and Statystyki Euroregionalnej [Centre for Research of Cross-border Regions and Euro-regional statistics], in https://rzeszow.stat.gov.pl (Accessed on 12.05.2020).

${ }^{26}$ Анастасія Стрижакова, Механізми державного управління розвитком транскордонного співробітництва між Україною та краӥнами Європейського Союзу [Mechanisms of Public Administration for the Development of Cross-border 
Any information support has great importance for the CBC socioeconomic efficiency since it stimulates information exchanges between its subjects, enhances and deepens good neighbourly relations among territorial communities and authorities. Any information asymmetry in CBC is unacceptable when uneven informational support of subjects occurs. ${ }^{27}$

As evidenced by research, the systems collecting and processing statistical information in Ukraine and Poland are significantly different and create obstacles in effectively using cross-border statistics. However, aspects of the CBC and the need to develop it to monitor specific problems of crossborder territories within the cross-border region are essential to reform its economy and improve its citizens' welfare successfully. The needs of CBC require, mainly concerning programming and monitoring, an updating system, a complete and credible economic database, and the social information on Ukraine's and Poland's border regions. It is necessary to establish and develop contacts among local authorities of border regions located in Poland and Ukraine. Some systematic statistical information exchanges among the regions of Ukraine and the neighbouring areas of the EU member-states are significant for this purpose, too. Moreover, it is essential to identify barriers that hinder entrepreneurship in the cross-border region beyond EU standards and create common regional development strategies and CBC plans in various spheres, promoting the Polish-Ukrainian cooperation in the cross-border areas. ${ }^{28}$

Simultaneously, the critical priorities regarding the informational support for the CBC of Ukraine with the EU neighbours are the establishment and support for business relationships between entrepreneurs, public, educational, governmental and non-governmental agencies in border regions of Ukraine and Poland, as well as the development and extension of CBC in the cultural sector, business, and its institutional evolution.29 These tasks are

Cooperation between Ukraine and the Countries of the European Union], Маріуполь, 2017, 248 с.

27 Святослав Жуков, Іван Чучка, Проблеми та перспективи інформаційномаркетингового забезпечення транскордонного співробітнищтва [Problems and Prospects of Information and Marketing Support for Cross-border Cooperation], in "Актуальні проблеми економіки" [Current problems of the есопоту], Київ, 10, 2007, p.74-81.

${ }^{28}$ Інформаційне забезпечення транскордонного співробітнищтва Украӥни: методичні аспекти [Information support of cross-border cooperation of Ukraine: methodological aspects], Луцьк, Вежа-Друк, 2015, 252 с.

${ }^{29}$ Wybrane aspekty współpracy transgranicznej polskich samorzq̨dów w kontekście przemian prawa Unii Europejskiej [Selected aspects of cross-border cooperation of 
solved, in particular, within the framework of measures, foreseen by the CBC Poland-Belarus-Ukraine Program. In particular, in 2008-2010, the Volyn Regional Support Fund in cooperation with the Podlasie Promotion Centre (Bialystok, Poland), ${ }^{30}$ Lublin Development Fund - Local Development Agency in Holm (Poland), the Department of Physical Culture, Sports and Tourism of Grodno Regional Executive Committee (Belarus) and the "Bug" Euroregion office (Ukraine) have developed a macro-project. The present Project under the name " Strengthening Cross-Border Cooperation in Business Services, Providing Easier Access for Entrepreneurs ", among others, was created by the Volyn Investment Attraction Agency. The information support for small and medium-sized start-ups has focused primarily, on innovative technologies and high-tech products. ${ }^{31}$

The "Bug" Euroregion geoportal ${ }^{32}$ is an IT tool for conducting spatial analysis, visualising data, and providing accessible disclosure via the Internet. For the first time in the history of the "Bug" Euroregion cross-border association, the information platform for the Ukrainian-Polish-Belarusian border territory of these three countries was developed. It contains tourist and economic information (tourist centres, hotels, restaurants, recreation places, campsites, historical and cultural monuments, reserves, infrastructure, investment and land sites, etc.) relative to Volyn and Brest regions, and Lublin Voivodship. The geoportal is beneficial for investors: it shows the vacant land plots of the Ukrainian-Polish-Belarusian border-zone. This will increase investors' potential interest in the allocation of financial resources in the territory of the Euroregion "Bug" including the Volyn region. Descriptions of all the tourist sites with brief references to them are available on this geoportal, giving opportunities for quick navigation of the path from one cultural and historical monument to another, saving time in preparing for holidays, excursion programs, and inspiring new travel ideas. The general concept of development of the Euroregion "Bug" up to 2020 is an attempt to create a basis for planning the border

Polish local governments in the context of changes in European Union law], Łódź, Wydawnictwo Naukowe Doctrina, 2016.

${ }^{30}$ Centrum promocji Podlasia [Podlasie promotion center], in https://poranny.pl/tag/centrum-promocji-podlasia (Accessed on 12.02.2020).

${ }^{31}$ Іван Артьомов, Моделі $і$ механізми регулювання єврорегіонального співробітництва України [Models and Mechanisms of Ukraine Euroregional Cooperation Development], Ужгород, Гражда 610, 2013, c.545-594.

32 Euroregion "Bug", in http://euroregionbug.maps.arcgis.com (Accessed on 12.05.2020). 
area's development. This document contains detailed information about the Euroregion "Bug" society, economy, environment, and infrastructure.

Within these macro-and micro-projects, aimed at the information support for entrepreneurial projects, in particular, "The Creation of UkrainianPolish Virtual Exchanges by Innovative Projects and Proposals", "Development of Cross-Border Business Cooperation in Border Regions", "The Development of Eco-Tourism and Positive Tourist Image of the Border Region" are implemented in the cross-border dimension.

This list is supplemented by Projects such as "Development of Cross-Border Cooperation in Improving Access to Small and Medium-Sized Enterprises to the Market of Financial Services", and "Improvement of the Investment Climate in Border Regions". The examples concerning the information support for CBC activities and resources, implemented through program projects, involve the training on "International Technical Assistance Programs", the international information and presentation workshop "Volyn Virtual Exchanges by Innovative Projects and Proposals". The Regional Innovative Centre website for transferring the latest technologies and the virtual exchanges by innovative projects and proposals was created. Even though the site, indicated herein, did not work as of December 2016, at the same time, it was noted that as a result of the Project, "hundreds of entrepreneurs from the Ukrainian-Polish border gained their experience in the formation and development of own business and in the management of innovative projects." 33 Another example of the crossborder activity relative to the information support in the entrepreneurship field was the Project "The Development of Cooperation between Volyn and Lublin in the Field of the Entrepreneurship Support." It enabled entrepreneurs to use the premises, telephones, workplaces, computers as well as consultations by lawyers, economists, and accountants. For business needs, the "PolishUkrainian Catalogue of Entrepreneurial Ideas on Business Development in Border Regions and Rural Areas" was published. It was focused on cross-border business projects. ${ }^{34}$

Therefore, the conclusion is that an important role in the information support system is assigned to subjects and objects, the combination of which

${ }^{33}$ Інформаційне забезпечення транскордонного співробітництва України: методичні аспекти [Information support of cross-border cooperation of Ukraine: methodological aspects], Луцьк, Вежа-Друк, 2015, 252 с.

${ }^{34}$ Natalia Hrynokh, Vitalii Dmytruk, Lidiia Diachenko, Anna Kniazevych, Social and economic aspects of cross-border cooperation of Ukraine and Poland in the field of tourism, in "Journal of Geology, Geography and Geoecology", Vol 28, No 3, 2019. 
depends on the level of the CBC organisational and legal forms. Based on the subject/object's status, on each side of the border, they are divided into two groups: direct participants and cross-border cooperation entities. The first group is mainly functioning at the local and regional levels. The latter represents CBC at all possible levels - international, national, regional and local. As a rule, issues concerning the cross-border information support interaction are treated by specialised structures of the regional authorities.

\section{ISSUES TO BE SOLVED AT ONCE}

For three years in a row (2013-2015), the Department of International Communications and Political Analysis of Lesya Ukrainka Eastern European National University has conducted a study on the topic "Cross-Border Cooperation Information Support" by Order of the Ministry of Education and Science, Youth and Sport of Ukraine. Research findings have resulted in the publication of three monographs. One of them ("The Information Support for Cross-Border Cooperation of Ukraine") outlines findings on informational support for a SWOT analysis of cross-border cooperation between Ukraine and its nearest neighbouring countries in three aspects: theoretical, practical and methodical. ${ }^{35}$ The study of results shows that authors have concluded that the factors listed below impact the effective information policy in the field of CBC: - Public awareness levels concerning the opportunities and perspectives of cross-border cooperation tools, and applicable to their professional and domestic activities, including the intensity of the reporting about the crossborder cooperation problems in the regional media;

- the levels of development of the institutional infrastructure of cross-border cooperation, as well as the staff training for the cross-border cooperation system;

- Communication infrastructure development levels (levels of access to crossborder cooperation participants to telephones and Internet resources while communicating with each other).

35 Інформаційне забезпечення транскордонного співробітнищтва Украӥни: теоретичні аспекти [Information support of cross-border cooperation of Ukraine: theoretical aspects], Луцьк, Вежа-Друк, 2013, 268 с.; Інформаційне забезпечення транскордонного співробітнищтва Украӥни: практичні аспекти [Information support of cross-border cooperation of Ukraine: practical aspects], Луцьк, Вежадрук, 2014, 288 с.; Інформаційне забезпечення транскордонного співробітництва України: методичні аспекти [Information support of cross-border cooperation of Ukraine: methodological aspects], Луцьк, Вежа-Друк, 2015, 252 c. 
The following points should be taken into consideration to enhance the information support for cross-border Programs with the aim to:

- make cross-border Projects more effective on the official web pages of regional, district, and city administrations by publishing the list and conditions for the relevant EU technical assistance programs, information dealing with Twinning and TAIEX activities, as well as their regional development strategy for CBC. The purpose of work in this direction is to harmonise Projects with regional, national and European priorities to achieve the coherence in the Project implementation in different periods and with various funding sources; - disseminate any information on Projects through the network of Ukraine diplomatic and consular institutions in neighbouring countries within the European Neighbourhood Instrument (ENI) (up to 2014 - the European Neighbourhood and Partnership Instrument - ENPI) to find partners. In particular, the successful implementation of the present Poland-BelarusUkraine Cross-Border Cooperation Program (2014-2020) will be particularly effective despite the low awareness of the ENP instruments; and the great interest of potential European collaboration to implement them.

The CBC news information support should be provided with the active media participation on both sides of the border, including television, radio, mass media, and online resources, providing significant opportunities for the cross-border region to present it as a particular economic, socio-political and cultural community. Informing residents from the cross-border areas on cultural and economic differences and common features helps remove communication and social barriers. Special attention needs to be given to the prospect to create scientific parks in Ukrainian-Polish cross-border regions, focused on a combination of intellectual and innovative operational monitoring of socio-economic processes between regional statistical offices. The creation of common cross-border information centres should become the key organisational mechanism.

To increase the project implementation efficiency, it is necessary to place the terms of relevant EU technical assistance programs and their regional strategy for the development of $\mathrm{CBC}$, on official web pages of regional, district, and city-state administrations. This is done to coordinate projects with regional, national and EU priorities and achieve consistency with different funding sources. ${ }^{36}$ The expansion of CBC informational support can be achieved through the promotion of $\mathrm{CBC}$ benefits and positive effects among the population of the

${ }^{36}$ Współpraca transgraniczna. Aspekty prawno ekonomiczne [Cross-border cooperation. Legal and economic aspects], Białystok, FundacjaPrawo i Partnerstwo, 2010. 
border regions, the informational support for the formation of initiative groups to promote $\mathrm{CBC}$ in its various forms and manifestations: border associations, cross-border non-governmental organisations, international business associations, multinational cultural societies, etc. Also, the creation of regional consulting organisations, information centres, and structures for the proper preparation of the CBC staff should be stepped up in the border regions. ${ }^{37}$

According to A. Strizhakova, ${ }^{38}$ the creation of information networks and governance structures as new forms of cross-border cooperation is, organizationally, advised:

- Information centres, and their activity, providing the information systematisation and dissemination for the cross-border cooperation participants on major CBC areas, innovative forms, cross-border projects, changes in legislation, individual programs, etc.

- Regional development agencies in regions, formed to maximise some legal, informational, and methodological support for cross-border cooperation target groups. In this case, any information and involvement of professionals, cross-border cooperation public, media and other target groups can be carried out by conducting relevant training and discussions, workshops, hearings, round table talks, working meetings with the direct participation of experts and public representatives.

- Specialised GIS (geographic information systems), which are used or can be implemented in the fields of the design, urban planning, sustainable territorial development, in the monitoring of the environmental systems and technogenic and ecological safety. Geo-information systems are varieties of information systems that provide the collection, storage, processing, access, display, and distribution of geographically coordinated (spatial) data.

- Cross-border cooperation centres (CBCC) as active forms of information support, executing the so-called outreach activities, promoting a scientific potential (higher education institutions) abroad, among academies, informing and providing personal consultations to the university staff on possible

37 Віталій Маркович, Соціально-економічна ефективність транскордонного співробітництва Украӥни в умовах європейської інтеграції [Socio-еconomic Efficiency of Ukraine Cross-border Cooperation in the Context of European Integration], Вінниця, 2018, 225 с.

${ }^{38}$ Анастасія Стрижакова, Механізми державного управління розвитком транскордонного співробітництва між Україною та країнами Європейського Союзу [Mechanisms of Public Administration for the Development of Cross-border Cooperation between Ukraine and the Countries of the European Union], Маріуполь, 2017, 248 с. 
cooperation areas mainly with partner organisations. Thus, such centres at Uzhhorod National University use opportunities to obtain extra-budgetary funding, hold presentations, workshops, and keep a coordinator of research information in the field.

Regional information-innovation-educational complexes aim to use the Internet technologies for interactive remote events, which allow holding educational and methodological, informational and discussion meetings in studios, specially equipped for it, on the principle of TV bridges, simultaneously in several regions.

- The Scientific, Technical and Economic Information Centre (CSTEI), able to perform the functions of a regional information-innovation-educational complex, with a regional information portal, created in its structure. The purpose of such a portal is to provide informed analysis and advisory electronic information channels for regional scientific and business circles, to form the innovative culture in the population, to monitor innovative processes, to search for new technologies and to implement them, as well as to promote the intellectual property commercialisation processes. The portal database's updating possibilities are substantially expanded through the precise coordination of the innovative proposals, received from research institutions, higher educational institutions, industrial enterprises, small and medium-sized businesses, and other economic entities of CBC member states.

The conduct of research in this study focused mainly on the Ukrainian side, primarily paying attention to the fact that the current political situation in this country led to a decrease in the bilateral relations between Poland and Ukraine, and, as a result, the close ties with the eastern border regions turned into a great loss. Most companies did not cope with the problematic situation due to their economic and political problems in Ukraine. Small institutions and enterprises, operating within the cross-border business field are in an even worse state. A significant challenge is that the areas in both countries with the most substantial international economic ties are located far from the border. ${ }^{39}$ Polish researchers confirmed some revival of the cooperation during the Euro 2012 football championship, where Poland and Ukraine were the countries of the final matches.

However, Ukraine remains Poland's leading strategic partner among the

${ }^{39}$ Bogdan Kawałko, Wybrane problemy polsko-ukraińskiej współpracy transgranicznej [Selected problems of Polish-Ukrainian cross-border cooperation],in“Barometr Regionalny" [Regional Barometer], Nr 2(24), 2011. 
non-EU countries. One can only agree with 0 . Charucka's opinion ${ }^{40}$ that the current state of cooperation in the Polish-Ukrainian border area cannot be characterised as effective cooperation. Its development is hampered by economic, legal, and other social factors. Despite the destabilisation in Ukraine, current Polish companies experience better times and stay in the Ukrainian market because of its vast potential, ranging from heavy industry to chemicals and agriculture. According to the World Bank data, this potential is developing and growing, while Ukraine is not the best suited for business. Further cooperation promotion depends on the progress of Ukraine's European integration processes and its local governmental reforms.

The huge problem, caused by the coronavirus pandemic, has also adjusted CBC structures' operability, including the information focus on the Programs. In particular, the Joint Monitoring Committee of the Poland-BelarusUkraine CBC Program 2014-2020 approved the allocation of an additional 3 million euros to finance 12 Projects (7 PL-BY, 4 PL-UA, 1 PL-BY-UA) in the field of health care, to support them in the fight against the Covid-19 outbreak. ${ }^{41}$

Various forms of the work online within the programs stay relevant. In connection with the cancellation of training on the Project implementation for beneficiaries of the conventional and large infrastructure projects in Poland, Belarus and Ukraine, all the training materials, prepared for these events, have been published on the site. The competition among journalists of different media types for the best publications concerning the Poland-Belarus-Ukraine Program in the mass media is planned. This competition is organised on the 30th anniversary of INTERREG. Its purpose is to promote the results of all three periods of the Program (2004-2006, 2007-2013 and 2014-2020) by demonstrating the Projects implemented under it in the form of text, audio, video, and television materials. Due to the competition, the support for the participants involved in the Project will be provided in the implementation of their information and promotion activities. Besides, the competition also aims at the integration of the journalistic environment from Poland, Belarus, and Ukraine.

Due to the epidemic situation caused by the COVID-19, the Cross-Border

40 Olga Charucka, Współpraca międzyregionalna i transgraniczna Polski z Ukrainq [Interregional and cross-border cooperation between Poland and Ukraine], in "ZNUV Vistula Zeszyty naukowe" [Vistula Scientific notebooks], 2016, 47(2), p.34-59.

41 Програма ТКС Польща-Білорусь-Україна 2014-2020, надасть 3 млн. євро для боротьби з Covid-19 [The program Poland-Belarus-Ukraine 2014-2020 will provide 3 million euros to combat Covid-19], 2020, in https://galinfo.com.ua/ news/programa_tks_polshchabilorusukraina_20142020_nadast_3_mln_ievro_dlya _borotby_z_covid19_343005.html (Accessed on 12.05.2020). 
Education Campaign for Schools has been cancelled this year, and the final event in Brest (Belarus) cannot be organised. Therefore, this campaign has been replaced by an online competition for teenagers under the same slogan "Together for Greener Tomorrow!"

\section{CONCLUSIONS}

Thus, cross-border cooperation has a systemic effect, aimed at the economic, social, scientific, technical, environmental, cultural, and other relations, established and deepened between the territorial communities, local executive bodies of Ukraine and the territorial communities and relevant authorities of other states, within their competence and national legislation. The cooperation across borders will help attract foreign investors, give some impetus to the production development, and provide a mechanism for implementing the idea of transport corridors. It is becoming more extensive, more inclusive and meaningful, encompassing more and more economic activities. With the formation of cross-border associations, there are ample opportunities in the economy, transport, environmental protection, energy, culture, development and modernisation of infrastructure, entrepreneurship, and disaster management. Opportunities are being created for a quick response to the market needs, mainly through appropriate cross-border integration.

Euroregions, cross-border cooperation participants and parties primarily tend to act within the framework of joint Projects and Programs, as sets of activities aimed at the development of cross-border cooperation which recently received state support and assistance under the EU Programs. A significant number of agreements and programs have been signed between Ukraine and Poland, which provide informational support to the CBC's organisational and legal systems. These programs' main problem is that more attention should be paid to common issues and positions of all the parties involved in the cooperation process.

The CBC information support for Ukraine and Poland is extensive and multilevel but remains unsystematic and ineffective within the framework of the "Carpathian" and the "Bug" Euroregions and their operability. There is a need within the functioning of the Ukrainian Euroregions, to improve the quality of the existing non-systemic informational interaction of regional entities, to ensure constant and continuous information to the public on both border sides, about the goals, principles, programs and specific projects of such cooperation. An important area of CBC development in the field of information support is the formation of specific cross-border statistics and the integration of monitoring 
systems. They are needed for the socio-economic processes between the regional statistical offices on both border sides. This may be achieved through the creation of joint cross-border information centres. Both the implementation and maintenance of cross-border statistics will enable the assessment of CBC development, will allow the analysis of the context of cross-border markets, conduct studies, and make management decisions on the regional development promptly.

\section{BIBLIOGRAPHY:}

1. Additional Protocol to the European Framework Convention on Cross-border Cooperation between Territorial Communities and Authorities, November 9, 1995.

2. $A E B R$, in aebr.eu

3. Centrum promocji Podlasia [Podlasie promotion center], in https://poranny.pl/ tag/centrum-promocji-podlasia

4. Charucka Olga, Współpraca międzyregionalna i transgraniczna Polski z Ukrainq [Interregional and cross-border cooperation between Poland and Ukraine], in "ZNUV Vistula Zeszyty naukowe" [Vistula Scientific notebooks], 2016, 47(2), p. 34-59.

5. ENI Poland-Belarus-Ukraine Cross-Border Cooperation Program 2014-2020, in https://www.pbu2020.eu/en/pages/251

6. Euroregion "Bug", in http://euroregionbug.maps.arcgis.com

7. Euroregion "Karpaty", in http://euroregionkarpaty.com.ua

8. Guimerà Antoni Durà, Camonita Francesco, Berzi Matteo, Noferini Andrea, Euroregions, Excellence and Innovation across EU borders, in A Catalogue of Good Practices, Barcelona, Department of Geography, UAB, 2018, 254 p.

9. Hooper Barbara, Kramsch Olivier (eds.), Cross-border governance in the European Union, Taylor \& Francis, 2004, 252 p.

10. Hrynokh Natalia, Dmytruk Vitalii, Diachenko Lidiia, Kniazevych Anna, Social and economic aspects of cross-border cooperation of Ukraine and Poland in the field of tourism, in "Journal of Geology, Geography and Geoecology", Vol 28, 2019, No 3.

11. Kawałko Bogdan, Wybrane problemy polsko-ukraińskiej współpracy transgranicznej [Selected problems of Polish-Ukrainian cross-border cooperation], in "Barometr Regionalny" [Regional Barometer], 2011, No. 2 (24).

12. Korop Bohdana, Miszczuk Andrzej, Czynniki peryferyzacji i aktywizacji regionów transgranicznych z udziałem Ukrainy - próbaujęcia typologicznego [Peripheral factors and activation of cross-border regions with the participation of Ukraine - an attempt at a typological approach], in "Wiadomości Statystyczne" [Statistical News], 10 (689), 2018, p. 5-20.

13. Krajowa Strategia Rozwoju Regionalnego 2010-2020 [National Strategy for Regional Development 2010-2020], in http://www.mrr.-gov.pl/rozwoj_regionalny/ polityka_regionalna/ksrr_2010_2020/Strony/Krajowa_Strategia_Rozwoju_Regionaln ego_2010_2020.aspx 
14. Medeiros Eduardo, (Re)defining the Euroregion Concept, in "European Planning Studies", 2011, 19(1), p. 141-158.

15. Medeiros Eduardo, Euro-Meso-Macro: The New Regions in Iberian and European Space, in "Regional Studies", 2013, 47(8), p. 1249-1266.

16. Osikowicz Żanna, Wspótpraca transgraniczna Ukrainy i Polski w strukturze stosunków międzynarodowych na przykładzie wybranych euroregionów (zarys i problematyka) [Cross-border cooperation of Ukraine and Poland in the structure of international relations on the example of selected euroregions (outline and issues)], in "Zarządzanie w Kulturze" [Management in Culture], 2017, 18, z. 2, s. 237-249.

17. Ośrodek Badań Obszarów Transgranicznych and Statystyki Euroregionalnej [Center for Research of Cross-border Regions and Euroregional statistics], in https://rzeszow.stat.gov.pl

18. Perkmann Markus, Cross-Border Regions in Europe: Significance and Drivers of Regional Cross-Border Co-operation, in "European Urban and Regional Studies", 2003, 10(2), p. 153-171.

19. Protocol No. 2 to the European Framework Convention on Cross-border Cooperation between Territorial Communities or Authorities, Concerning Inter-territorial Cooperation (1998, 5.05), Strasbourg.

20. Strategia rozwoju społeczno-gospodarczego z Polska do 2020 roku [Strategy for socio-economic development from Poland to 2020], in http://www.polskawschodnia.gov.pl/Dokumenty/Lists/Dokumenty\%20programow e/Attachments/93/Strategia_PW_po_RM.pdf

21. Strategia Rozwoju Województwa Lubelskiego [Development Strategy of the Lubelskie Voivodship], in http://www.-rpo.lubelskie.pl/front/page/get/281/.94

22. Strategia Rozwoju Województwa Podkarpackiego [Development Strategy of the Podkarpackie Voivodeship], in www.podkarpackie.pl/strategia/strat_woj.pdf

23. Współpraca transgraniczna. Aspekty prawno ekonomiczne [Cross-border cooperation. Legal and economic aspects], Białystok, Fundacja Prawo i Partnerstwo, 2010.

24. Wybrane aspekty współpracy transgranicznej polskich samorządów w kontekście przemian prawa Unii Europejskiej [Selected aspects of cross-border cooperation of Polish local governments in the context of changes in European Union law], Łódź, Wydawnictwo Naukowe Doctrina, 2016.

25. Артьомов Іван, Моделі і механізми регулювання єврорегіонального співробітництва України [Models and Mechanisms of Ukraine Euroregional Cooperation Development], Ужгород, Гражда, 610, 2013, с. 545-594.

26. Бєлєнький Петро, Мікула Надія, Матвєєв Євгеній, Конкурентність на транскордонних ринках [Competitiveness in cross-border markets], Львів, 2005, 214 с.

27. Жуков Святослав, Чучка Іван, Проблеми та перспективи інформаційномаркетингового забезпечення транскордонного співробітництва [Problems and Prospects of Information and Marketing Support for Cross-border Cooperation], in “Актуальні проблеми економіки" [Current problems of the economy], Київ, 10, 2007, с. 74-81. 
28. Закон України Про транскордонне співробітництво [Law of Ukraine "On Cross-Border Cooperation”] №1861-IV від 24.06.2004, in http://zakon3.rada.gov.ua/ laws/show/1861-15

29. Інформаційна підтримка бенефіціарів PBU1/LIP [Information support of beneficiaries], in https://www.pbu2020.eu/ua/news/1501

30. Інформаційне забезпечення транскордонного співробітнищтва України: практичні аспекти [Information support of cross-border cooperation of Ukraine: practical aspects], Луцьк, Вежа-друк, 2014, 288 с.

31. Інформаційне забезпечення транскордонного співробітництва Украӥни: методичні аспекти [Information support of cross-border cooperation of Ukraine: methodological aspects], Луцьк, Вежа-Друк, 2015, 252 c.

32. Кіш Євген, Проблеми транскордонного співробітництва Украӥни $i$ Євросоюзу [Problems of Cross-border Cooperation between Ukraine and the European Union], in http://www.politik.org.ua/vid/magcontent.php3?m=1\&n=63\&c=1412

33. Маркович Віталій, Соціально-економічна ефективність транскордонного співробітнищтва України в умовах європейської інтеграції [Socio-еconomic Efficiency of Ukraine Cross-border Cooperation in the Context of European Integration], Вінниця, 2018, 225 с.

34. Мікула Надія, Єврорегіони: досвід та перспективи [Euroregions: Experience and Perspectives], Львів, ІРД НАН України, 2003, 222 с.

35. На шляху до Європи. Український досвід єврорегіонів [On the way to Europe. Ukrainian experience of Euroregions], К.: Логос, 2000, 221 c.

36. Програма ТКС Польща-Білорусь-Україна 2014-2020, надасть 3 млн. євро для боротьби з Covid-19 [The program Poland-Belarus-Ukraine 2014-2020 will provide 3 million euros to combat Covid-19], 2020, in https://galinfo.com.ua/news/ programa_tks_polshchabilorusukraina_20142020_nadast_3_mln_ievro_dlya_borotby_ z_covid19_343005.html

37. Статистичний кластер [Statistical cluster], in http://www.lv.ukrstat.gov.ua/CBC/ua/project/project_all.php?u=4\&l1=1

38. Стеченко Дмитро, Розміщення продуктивних сил $i$ регіоналістика [Productive Forces Deployment and Regionalism], Київ, Вікар, 2006, 396 с.

39. Стрижакова Анастасія, Механізми державного управління розвитком транскордонного співробітництва між Україною та краӥнами Європейського Союзу [Mechanisms of Public Administration for the Development of Cross-border Cooperation between Ukraine and the Countries of the European Union], Маріуполь, 2017, 248 c.

40. Товканець Сергій, Товканець Ганна, Інформаційне забезпечення міжнародного бізнесу в рамках транскордонного співробітнищтва [Information support of international business in the framework of cross-border cooperation], in “Актуальні проблеми економіки" [Current problems of the economy], 2010, 10 (112), c. 281-287. 